\title{
Patterns of innovation in the EU-25 regions: a typology and policy recommendations
}

\section{Mikel Navarro, Juan José Gibaja, Ricardo Aguado, Beñat Bilbao}

Mikel Navarro, Orkestra-Basque Institute of Competitiveness mnavarro@orkestra.deusto.es

Juan José Gibaja, Orkestra-Basque Institute of Competitiveness jgibaja@orkestra.deusto.es

Ricardo Aguado, Orkestra-Basque Institute of Competitiveness raguado@orkestra.deusto.es Beñat Bilbao-Osorio, OECD Benat.BILBAO-OSORIO@oecd.org

Keywords:

Innovation, Regional Innovation Systems, European Union, Typology, Principal Components Analysis, Cluster Analysis

JEL Codes:

R11, O18, O33, O38 


\section{Patterns of innovation in the EU-25 regions: a typology and policy recommendations}

This paper depicts a typology of regions, capturing the/diversity of regional innovation systems across the EU-25. Following the Regional Innovation Systems (RIS) literature, our research selects 21 variables related to the ability of a region to generate and absorb knowledge, and its capacity to transform R\&D into innovation and economic growth. Based on the results of principal components and cluster analyses, we identify seven types of regional innovation system where the 186 regions group together according to their sectoral specialization, technological and economic capacity, and performance. By allowing us to identify similar and more advanced regions, the paper facilitates comparisons and benchmarking between homogeneous regions, thus enabling more accurate policy learning. For each group a number of policy recommendations are suggested, contingent to their local-specific characteristics. In short the contribution of this paper is twofold. In the first place it provides the first RIS typology for the EU-25 regions completed using a large number of variables. Secondly, the conclusions obtained from the analysis may be used to lead policymakers' actions in the field of regional innovation policy in the EU.

\section{Patrones regionales de innovación en la UE-25: tipología y recomendaciones de políticas}

Este documento desarrolla una tipología de regiones que recoge la diversidad de patrones regionales de innovación existentes en la UE-25. Para ello selecciona 21 variables relacionadas con la capacidad de una región para generar y absorber conocimiento y para transformar la I+D en innovación y crecimiento económico. A partir de los resultados de sendos análisis de componentes principales y clúster, se identifican 7 tipos de patrones/regionales de innovación, en los que se agrupan las 186 regiones de laUE25, de acuerdo con su especialización sectorial y su capacidad y desempeño económico y tecnológico. Identificando regiones similares o más avanzadas se facilitan comparaciones entre regiones homogéneas, de los que derivar aprendizajes de políticas acertadas. Para cada uno de los 7 grupos el artículo ofrece recomendaciones de políticas, acordes a sus características locales específicas. En suma, la contribución de este documento es doble: en primer lugar, provee la primera tipología de patrones de innovación para las regiones de la UE-25, obtenida a partir de un número elevado de variables; y, en segundo lugar, las conclusiones derivadas del análisis pueden guiar las actuaciones de los responsables políticos de la UE en el campo de las políticas de innovación regional.

\section{Berrikuntzako eskualdeko ereduak EB-25ean: tipologia eta politiken gomendioak}

Dokumentu honetan eskualdeen tipologia bat garatu dugu, EB-25eko berrikuntzako eskualdeko/eredu askotarikoak biltzeko. Horretarako 21 aldagai aukeratu ditugu, eskualde batek jakintza sortzeko eta bereganatzeko eta I+G berrikuntza eta hazkunde ekonomiko bihurtzeko duen gaitasunarekin lotura dutenak. Osagai nagusizko analisiaren eta kluster analisiaren emaitzetatik abiatuta, berrikuntzako eskualdeko 7 eredu identifikatu ditugu. 7 eredu horietan multzokatu ditugu EB-25eko 186 eskualdeak, sektore espezializazioaren eta ekonomi eta teknologi gaitasun eta emaitzen arabera. Antzeko eskualdeak edo eskualde aurreratuagoak identifikatzean, eskualde homogeneoen arteko alderapenak egin daitezke eta horietatik, politika egokiak ikasi. 7 talde horietako bakoitzerako, artikuluak politiken gomendioak eskaintzen dizkigu, tokiko ezaugarri bereziak kontuan hartuta. Laburbilduz, dokumentu honek ekarpen bikoitza egiten du: lehenengo, EB-25eko eskualdeentzat berrikuntzako ereduen lehenengo tipologia eskaintzen du, aldagai kopuru handia oinarri hartuta osatua; bigarren, analisi honetatik ateratako ondorioak EBko arduradun politikoen jardunean lagungarri izan daitezke, berrikuntzako eskualdeko politikei dagokienez. 


\section{Introduction $^{\phi}$.}

Both in literature and in policy implementation in the industrial, technological and regional fields there is a growing and converging tendency towards taking territory and innovation as primary objects of attention (Porter 1998, Malmberg and Maskell 1997, Cooke and Morgan 1998). However, the mentioned literature has a clear bias in its empirical investigation towards case study analysis (MacKinnon et al. 2002, Doloreux 2004). The use of empirical analyses based on aggregated data from secondary sources has been seldom used (Malmberg and Maskell 1997). One of the objectives of this work is to contribute to the creation of a more robust empirical research using quantitative methods. More precisely, this paper aims to obtain a typology of regions capturing the diversity of the regional innovation systems across the EU-25.

Although research in this field is relatively scarce, some previous studies have offered typologies of European regions based on their economic and technological capacities and performances. The typology coming up from this paper is differentiated by the use of a large number of variables (more than 20 , extracted from the REGUE database ${ }^{1}$ ), its wide coverage, as the whole EU-25 in analysed, the use of recent data, as 2004 data are used, and by taking into account variables not considered by other works, such as peripherality.

Following Asheim and Gertler (2005: 299), the RIS could be defined as the "institutional infrastructure supporting innovation within the production structure of a region". As a result of this definition, the regions would be expected to group according to their technological development and productive structure. At the same time, the regional innovation systems and peripherality literatures suggest that central and urban regions, with a higher percentage of employment in financial and business services, present a greater innovative input and

\footnotetext{
${ }^{\phi}$ We would like to thank James Wilson and other members of the Chair Clusters, innovation systems and regional development (Orkestra. Basque Institute of Competitiveness) for their kind comments on this paper. Usual disclaims apply.

${ }_{1}^{1}$ The REGUE dataset has been jointly developed by the IAIF and the Basque Institute of Competitiveness based on data contained in Eurostat-Regions and own estimations
} 
technological and economic performance (Scott and Storper 2003; Cooke et al. 2002; Schürmann and Talaat 2000; Spiekermann and Neubauer 2002).

Just as firms look and compare to similar firms in terms of size, technological development or sectoral specialization, Governments, either at the regional or national level, can look at policies developed elsewhere to learn from other experiences and decide which policies could be implemented (Malik and Cunningham, 2006). This paper aims at identifying homogeneous sets of regions so that innovation policy learning can be more targeted and where broad policy recommendations can be more oriented.

\section{Territory, innovation and policy learning}

In the competitiveness, innovation and economic development literature, as well as in the management of industrial, technological and regional development policies, the need to focus on the sub-national level has become increasingly important.

- In the competitiveness literature, there is a growing tendency to give priority to micro aspects over macro, whether such micro aspects are of a general nature (territory diamond) or specific nature (cluster diamond). These micro aspects are considered to be largely determined at the subnational level (Porter 1998 and 2003).

- The recent innovation literature abandons the linear model of innovation and portraits innovation as the result of an iterative process of highly localised social actors and their interactions (Lundvall 1992). These localised interactions between agents are largely due to the physical proximity needed for the transmission of tacit knowledge (Braczyck et al. 1998, Malmberg and Maskell 1997, Maskell and Malmberg 1999).

- Finally, the regional development literature recognises the importance of endogenous development and the impact that innovative capacity has on the territory (Cooke and Morgan 1998, Morgan 2004). 
In short, in recent years, analysts and industrial, technological and regional policy makers have realised that competitiveness and innovation are primarily determined at the regional and local levels (OECD 2001 and 2007).

In the economics literature, there are several schools or trends that analyse innovation at the regional and local levels, developing theoretical frameworks: industrial districts, innovative milieu, local production systems, learning regions, technological districts, etc. (Moulaert and Sekia 2003). Among those trends, the regional innovation systems (RIS) approach has particularly stood out thanks to the development of a vast literature and its wide acceptance among policy makers and international institutions dealing with economic development (European Commission, OECD, World Bank).

In addition to the lack of precision, clarity and rigour in many of its concepts, criticised by some authors (Doloreux 2004, Hommen and Doloreux 2003, MacKinnon et al. 2002, Andersson and Karlsson 2004, Fernández-Satto and Vigil-Greco 2007), the development of the RIS literature has been hampered by the lack of indicators and sources to analyse the RIS empirically. This may explain the current bias of the literature towards the theory and the lack of empirical studies (MacKinnon et al. 2002). Moreover, the scarce empirical literature has mainly developed based on case studies, mostly limited to successful regions (Doloreux 2004, Howells 2005, Sharpe and MartínezFernández 2006). These case studies provide a static snapshot rather than the dynamic adjustment processes enabled by longitudinal studies (Doloreux and Parto 2004, MacKinnon et al. 2002, Salom 2003). In this regard, Malmberg and Maskell (1997) have criticised the lack of studies in the RIS literature that use aggregated data for a large number of regions, usually taken from secondary sources. This article aims precisely to bridge this existing gap in the literature.

Among all of the aspects in which the RIS literature has tried to advance empirical studies, this article focuses on obtaining a typology of European regions. This will help capture the extraordinary diversity and richness of this 
empirical phenomenon and conduct benchmarking studies for the design of better adapted policies to the characteristics of each territory.

Governments, either at the regional or national level are increasingly conscious of the need of implementing policies aiming at enhancing the innovative profile of their territories. However, designing and implementing innovation policies is not an easy task, and "radical innovations 2 " in terms of policy developments are rare and risky. As incremental innovations in firms are more common than radical innovations and firms tend to look and learn from new products and processes developed in other firms, governments also look at policies developed elsewhere to learn from other experiences and decide which policies could be implemented. However, a direct transposition of policies and measures is not always, if ever, possible. As the regional innovation system theory explains, innovation policies and measures are diverse in both nature and scope depending on the conditions embedded in the territory. As a result structural characteristics and governing set-ups influencing innovation are crucial factors when copying or adapting policies developed elsewhere. In order to foster innovation policy learning, regions should look at other regions which are similar in terms of structural characteristics and factors affecting innovations, as the policy instruments and measures working on these regions may be more targeted and suited to the local conditions.

\section{The literature on regional typologies of innovation}

There have been two approaches for obtaining regional typologies of innovation. The first one deals with authors who used case studies, sometimes as an iterative dialogue, in order to test previous conceptual works. Cooke (1998) combined three types of RIS governance (grassroots, network and interventionist) with other three dimensions of entrepreneurial innovation (localist, interactive and globalised). As a result, he achieved a typology of 9 groups of RIS. Asheim (2007) distinguished between three types of RIS: territorially embedded, regionally networked and regionalised nationals. Lastly,

\footnotetext{
${ }^{2}$ Radical innovation in this context can be defined as the development of policy measures never carried out before in any other territory.
} 
Tödtling and Trippl (2005) classify the regions in peripheral, mature industrial and metropolitan regions.

The second way to create regional taxonomies of innovation has used statistical analysis for a wide set of regions. A brief summary of the empirical work in this field has resulted in the typologies listed in table 1. Our approach goes in line with this type of econometric studies.

Regional innovation researchers in Europe face a constant challenge due to the lack of available regional data related to innovation. As a result, the type of variables and concepts that RIS researchers use in their statistical analyses are highly influenced by the cross-regional available data. RIS analysts have complained about the lack of internationally comparable statistical sources that provide regional data for a significant number of countries. Lately, the data availability has improved substantially, thanks to the fact that access to this information has become free, the Regions database of Eurostat has expanded to include more variables, and the ESPON base has come up to supplement the previously available information for some fields. In fact, most of the researchers listed in table 1 have used regional data published by Eurostat, supplemented in some cases with author's own exploitations of other nonofficial sources.

Most of the cited studies have punctually come to Eurostat and selected the variables relevant for their analyses. Some other research teams, however, using data based largely on Eurostat, have tried to develop their own databases on regional innovation indicators for the EU, including a significant number of variables. One of those teams is the Institute for Industrial and Financial Analysis (IAIF) from the Complutense University of Madrid, which have developed the IAIF-RIS (EU) database for 146 regions of the EU-15. This database includes 65 variables grouped into the following categories: patents, innovative effort, structural conditions in the region, human resources in science and technology, and support elements to innovation, for the period $1995-2001^{3}$.

\footnotetext{
${ }^{3}$ In parallel to the IAIF-RIS (EU) database the team from IAIF have developed the IAIF-RIS (Spain) database specifically for Spanish regions, using a similar management scheme but with
} 
In order to fill the existing data gaps from the Regions database, the IAIF team estimated $^{4}$ some of the data for some variables, regions and years.

Recently the IAIF-RIS dataset has been updated by the IAIF in cooperation with the Basque Institute of Competitiveness, increasing the number of variables to 175 (not counting the variables expressed in constant euros). This new dataset, called REGUE, covers the 1995-2004 period. Moreover, in addition to the EU15countries, it includes the 10 new Member States countries after the 2004 enlargement.

The new available data have helped this investigation to answer to three crucial issues posed by the literature dealing with the relationship between territory and innovation.

First of all, with regard to the territorial scope of the analysis, it is about the regional level. According to Cooke (2005: 1134) "region is an administrative division of a country (...) nested territorially beneath the level of the country, but above the local or municipal level". Furthermore, as the mentioned author says: "in the field of regional development 'to govern' is precisely the sense of 'region' intended, namely governance of policies to assist processes of economic development". When the IAIF-RIS (EU) database was set up, a study of the sub-national territorial organisation of the EU was conducted, and the regulatory and functional criteria in the NUTS system and their application by the state members taken into account ${ }^{5}$. In this analysis, it was decided to include only those geographical areas with a political and administrative equivalence. Based on these criteria, the following geographical units were identified for analysis:

- NUTS 1: Belgium, Germany, United Kingdom.

a greater wealth of variables. This database has been exploited by members of the IAIF in numerous publications, among which we should underline Buesa et al. (2002), Buesa et al. (2003a and 2003b), Martinez-Pellitero (2002), Martinez-Pellitero and Baumert (2003) and Buesa et al. (2007).

${ }^{4} \mathrm{~A}$ complete description of the database is in the doctoral thesis of Baumert (2006).

${ }^{5}$ See Baumert (2006), especially pages 79-88 and 233-247. 
- NUTS 2: Spain, France, Italy, Netherlands, Austria, Portugal, Finland, Sweden, Czech Republic, Hungary, Poland, Slovak Republic.

- Countries where there are no subdivisions, because of small territorial extension: Ireland, Luxembourg, Denmark, Cyprus, Estonia, Latvia, Lithuania, Malta, Slovenia.

The geographical area covered in this research is the EU-25. Although the works of Ecotec (2005) and Hollanders (2007) also offer typologies for the EU25 (or EU-27), these typologies are based on a smaller number of indicators than the ones proposed in this paper. Besides these studies, almost any other typologies of European regions refer to the EU-15, or to EU-10, but not to the whole of the EU-25.

Secondly, most of the literature on territory and innovation tries to tackle the issue from a systemic point of view (Edquist 2005). As Fritz (2002) rightly points out, it is precisely the interaction, the density and quality of the network operations among the elements of the system that are decisive. The point is that secondary data sources do not provide data about the interactions between the components of the system, let alone the linkages with members of other systems of innovation (regional, national or international). As a result, and bearing in mind the limitation that these unavailable data impose, the use of statistical techniques can only offer regional patterns of innovation, rather than types of RIS. Nevertheless, there are authors like Nelson (1992), who employ the term system in a purely pragmatic way, understanding by a system "a set of institutions whose interactions determine the innovative performance...(with) no presumption that the system is consciously designed, or even that the set of institutions involved works together smoothly and coherently". Therefore, as long as the secondary data sources allow us to assess the weight and behaviour of the main components of the system (firms, universities and government) in some key innovating activities (eg $R \& D$ ), regional typologies of innovation derived from them could be considered to correspond to regional innovation systems, in a broad sense. 
Third, and finally, with regard to the kind of innovation laying behind the typology, the lack of regional data on non-technological innovation and labour mobility of researchers, scientists and technicians makes this kind of analysis impossible. There are many other basic indicators of innovation which are not available for regions. An example of this is the fact that the European Innovation Scoreboard 2006 has been calculated for national states based on 26 indicators, while the European Regional Innovation Scoreboard (2006 RIS) has been calculated only with 7 indicators (see them in Hollanders 2007, mentioned in table 1)

Muller and Nauwelaers (2005) identify two types of key indicators that have been used in the different studies of EU RIS: first, those indicators closely related to $R \& D$ and technology, and second, those indicators related to the degree of regional economic development. The innovation capacity of a region depends on its absorptive and knowledge creation capacities, and on their social, political and economic characteristics, as they can be innovation filters or powers that hamper or enhance the regional ability to transform their R\&D investment into innovation and economic growth (Bilbao-Osorio and RodriguezPose 2004).

In our research, 21 indicators have been selected. Twenty of these indicators belong to the REGUE database, while one, the peripherality index, has been taken from the Schürmann and Talaat (2000) study. Table 2 presents a description of these indicators.

A) The first 10 indicators were selected to reflect the socio-economic characteristics of a region. They include indicators such as per capita GDP and productivity, which can be considered as proxies of the stock of knowledge of a country (Bilbao-Osorio and Rodriguez-Pose 2004) and the degree of sophistication of its demand (Muller and Nauwelaers 2005). As table 3 shows, both of them (especially the GDP per capita) have been used in the construction of other typologies.

B) The employment rate and other productive structure related indicators are 
proxies of the "social filters" of a region, of the regional ability to transform R\&D into innovation and economic growth (Rodriguez-Pose 1999, Crescenzi et al. 2007). These indicators have been also widely used in other studies, especially in those linking employment to the technological level of the productive sectors. The only indicator which has not been previously used is the employment in business and financial services. This variable may be the best proxy for knowledge intensive business services. These type of services are positively correlated with the summary index of European innovation (Arundel et al. 2007) and with the regional economic and technological performance (Miles 2005).

C) Population density, as indicated by Sterlacchini (2006) or Crescenzi et al. (2007), can be regarded as a proxy for the economies of agglomeration. As for the peripherality index -understood not as an indicator of development, but as an indicator of accessibility- its introduction is justified as the proximity to markets and developed technological locations, facilitates the presence of spillovers and external economies (Crescenzi et al. 2007). This paper is the first to take account the peripherality index in order to generate a EU-25 RIS typology ${ }^{6}$.

D) In addition to these ten socio-economic indicators, the present research also introduces indicators to proxy the knowledge and technological absorptive capacity of a region: The four indicators related to education and human resources in science and technology virtually match those included in the European Innovation Scoreboard 2006, and distinguish, as Ecotec (2005), between general education and the qualification of human resources linked to R\&D activities.

E) Unlike other RIS typologies, this work has also taken into account the R\&D expenditure per occupied person in R\&D activities. As the Key figures 2007 on Science, Technology and Innovation. Towards an European Knowledge Area shows, R\&D workers' compensations are much lower in less developed

\footnotetext{
${ }^{6}$ In the following pages, we will use the name "peripheral region" (or not easily accessible) to refer to a region with a value in the index lower than or equal to 100 and not peripheral (or accessible) for those with a value greater than 100 .
} 
regions. If we look only at $R \& D$ expenditure, differences between developed and less developed regions could be magnified.

F) Indicators on expenditure on R\&D and patents, as in most other studies (see table 3), are included as proxies for knowledge creation. Although in other studies, R\&D in tertiary education and public administration have been included in the category of public $R \& D$, in our research, we have distinguished the two types of R\&D, as they may carry out different types of research. Besides, the weight and role assigned to the public administration or the university is different in each country (Mowery and Sampat 2005). Although tertiary education is more widespread, R\&D activities linked to the public administration tend to concentrate in certain regions (Oughton et al. 2002).

To sum up, this study considers 21 indicators to build a typology of the EU-25 RIS. The indicators are calculated for 2004, except for the peripherality index, which refers to 2000. Moreover, a multiple factor analysis for the years 2000 , 2002 and 2004 was conducted, showing very little volatility during the five years where complete data were available for all analysed regions.

\section{Methodology of Data Analysis}

Data analysis was performed using SPSS v.15 and SPAD v5.5. This analysis has gone through three phases, which are presented as a function of the multivariate techniques employed:

- Principal components analysis on original variables and growth rates.

- Principal components analysis and cluster analysis on original variables and peripherality index.

- Multiple factor analysis on original variables. 
Although our research, as those of Muller and Nauwelaers (2005) and MartinezPellitero (2007), uses more than twenty indicators, it does not use synthetic indicators as in these cases. Working with the original indicators facilitates the interpretation of the econometric results, and therefore the suggestions of policy recommendations.

A review of the empirical literature about RIS typologies recommends the inclusion of not only the levels of the variables chosen, but also their growth rates. Clarysse and Muldur (1999), Muller and Nauwelaers (2005) and Bruijn and Lagendijk (2005) use dynamic indicators to build their groups. Therefore, our research initially considered both annual indicators and growth rates. Nevertheless, results obtained from elaborating a principal components analysis (PCA) on the levels and growth rates of the variables were not too good in terms of percentages of variability collected in the first two components. The consideration of growth rates allowed us to detect a catch-up effect in the less developed regions, which also showed a tendency to be associated with higher values in growth rates. However, the contribution of the latter to the characterization of the groups of regions was minimal. Moreover, they made the interpretation of the factors less intuitive and therefore it was decided not to include them in the analysis.

Because of this, we opted to use the PCA technique on the levels of variables. To these variables was added another one as a result of the review of the literature: the peripherality index, which is an indicator of accessibility of the regions. With this set of variables a PCA was elaborated for all regions of the EU-25. The data considered were, in all cases, those referring to the year 2004 (except the peripherality index, which refers to 2000; but because of its structural nature this index will not experience substantial changes). After each PCA, the correspondent cluster analysis was conducted. This cluster analysis let us establish the present typology of regions in the EU-25.

Finally, in order to include the evolutionary effect, we used multiple factor analysis (MFA). According to Abascal and Landaluce (2002) MFA is effective to analyse the stability of results obtained using a PCA. With this goal in mind a 
MFA was made on the regions of the EU-25. The data taken into account were those relating to the years 2000, 2002 and 2004. The result of MFA assured the stability of the results: the original variables are of a structural nature - very little volatility - and non-significant differences were observed between European regions in the five-year period under consideration. The results of these analyses are presented below, in the next section.

\section{Typologies for the EU-25 regions}

We develop a principal components analysis with the 21 variables that have been summarised in table 2 for the 186 regions of the EU. In figure 1 the positions of the variables regarding the first two principal components are shown. The first principal component, measured in the horizontal axis, explains $41.05 \%$ of the variance and represents, to a great extent, economic and technological development, as it is shown by the coordinates of per capita GDP, productivity, population density, employment in high-tech services, employment in financial and business services, inputs in R\&D and results of R\&D activities. The second principal component, measured in the vertical axis, explains $11.75 \%$ of the variance and represents the regional sectoral specialisation, as it is shown by the coordinates of industrial employment and employment in medium-high and high-tech manufactures.

In figure 2 the position of the EU-25 regions regarding the two principal components is displayed. The centre of gravity of each of the seven groups of regions that have been identified in the cluster analysis is also illustrated. The size of each centroid represents the number of regions belonging to each group. Moreover, the regions belonging to the EU-10 enlargement countries and to the EU-15 countries that formed the Union before the enlargement appear with distinctive symbols and colours. Finally, the peripheral regions (those that do not exceed 100 in the peripherality index) are highlighted. In short, the figure can be interpreted as such: regions with high levels of economic and technological development will be located in the extreme right of Figure 2; regions with a low percentage of industrial employment and employment in medium-high or high-tech manufactures will be placed in the 
upper position; regions situated in the lower part will have a high percentage of employment in these two sectors.

Figure 1. Results of the principal components analysis for the EU-25 regions

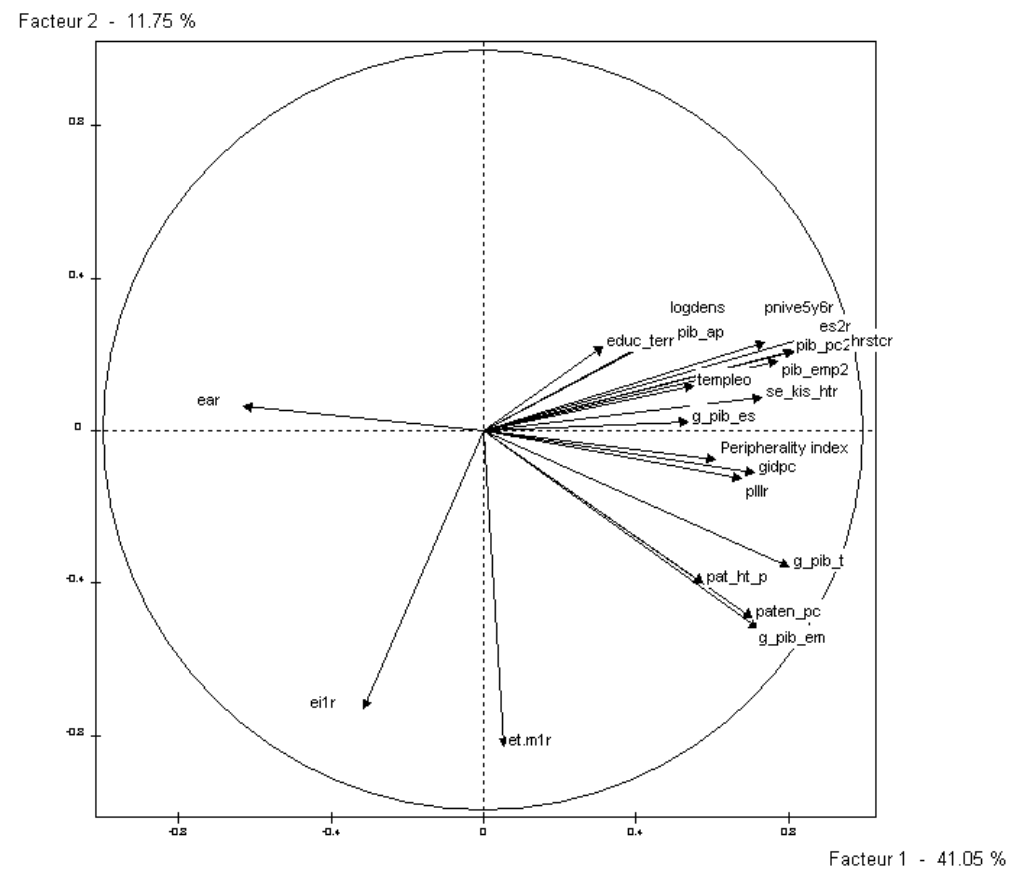

Figure 2. Location of the EU-25 regions regarding the two first principal components: Regional typology according to the cluster analysis

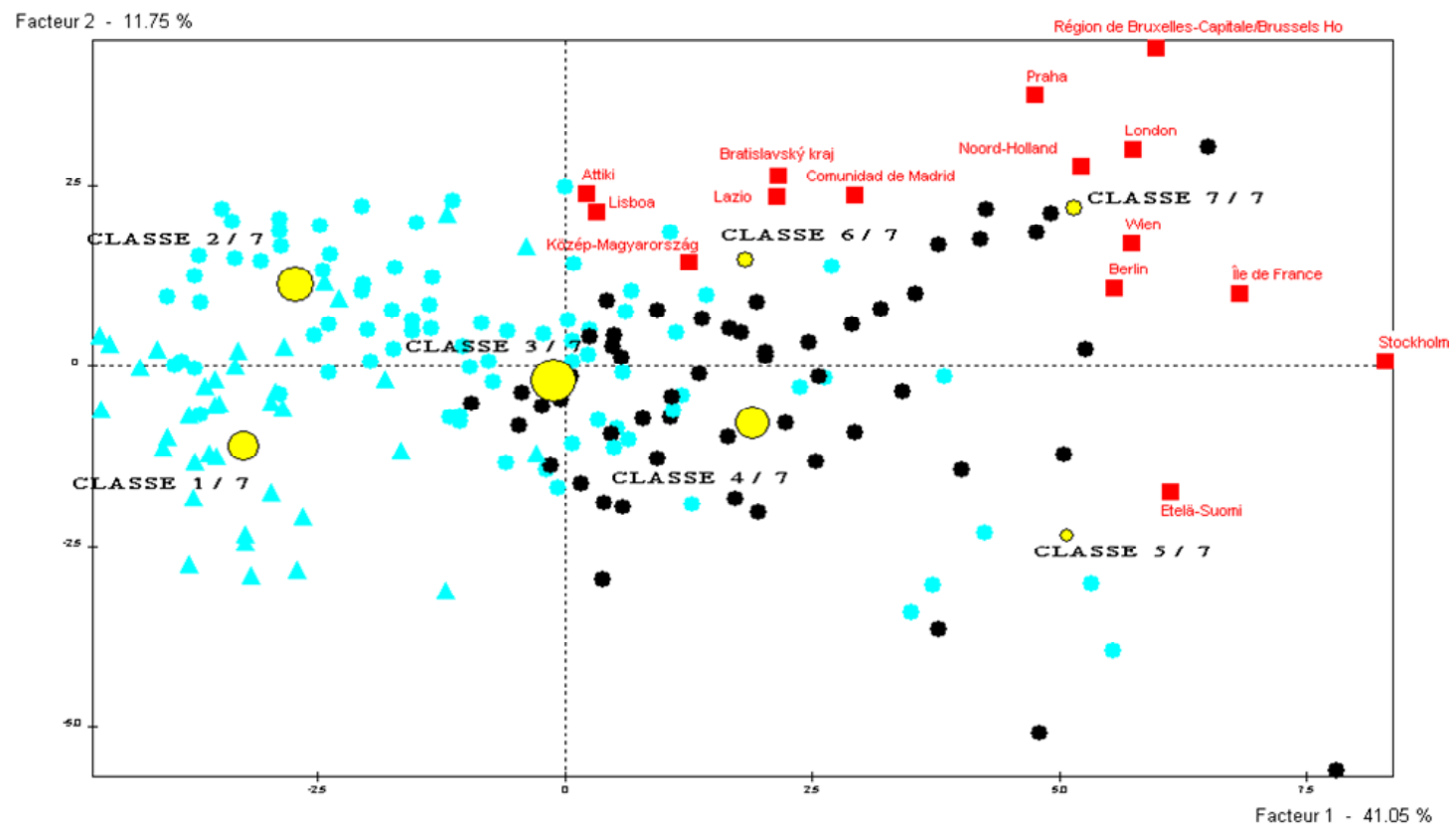

Key for colours and symbols:

Black: peripherality index $>100$; cyan: peripherality index $<=100$

Circle: UE-15; Triangle: UE-10

Capital Regions: stressed in red with the name 
Figure 2 reveals a relationship between economic and technological development and peripherality. Although there is not a complete determinism, regions with more accessibility tend to concentrate in the right part of the point cloud (developed regions). On the other hand, regions with low accessibility tend to concentrate in the left part, related to low levels of development and low levels of R\&D output. It is possible to see, also, that regions belonging to the enlargement countries are prone to concentrate in the left part of figure 2 . However, some of those regions have achieved a good performance and are part of groups 3, 6 and 7. They tend to locate in the upper part of figure 2. This means they are not specialised in industry but in high value-added services. Finally, figure 2 shows that the EU-25 capital-regions ${ }^{7}$ are mainly located in the upper-right corner, in groups 6 and 7. This fact makes explicit the link between being a capital-region and achieving a high level of economic and technological development. It makes clear, also, the low level of employment in industrial activities in this type of region.

Membership of each group is shown in table 4. The features of the seven groups are summarised in the following titles:

- G1: Restructuring industrial regions with strong weaknesses

- G2: Regions with a weak economic and technological performance

- G3: Regions with average economic and technological performance

- G4: Advanced regions, with a certain industrial specialisation

- G5: Innovative regions, with a high level of economic and technological development

- G6: Capital-regions, with a certain specialisation in high value-added services

- G7: Innovative capital-regions, specialised in high value-added services

\footnotetext{
${ }^{7}$ We speak about capital-regions only if the country has sub-national administrative levels. In this paper we exclude from this category the cases of Ireland, Luxemburg, Denmark, Cyprus, Estonia, Latvia, Lithuania, Malta and Slovenia because in those countries there are not subnational levels.
} 
A first comparison between the typology obtained in this paper with those offered by other authors (see table 1) reveals that the number of groups of the present work is situated in an intermediate position between the 5 groups of Muller and Nauwelaers (2005) and Ecotec (2005) and the 10-12 groups found by Martínez-Pellitero (2007) and Hollanders (2007). In general, the majority of typologies offer 5-6 groups.

\section{Table 4: Groups of EU-25 regions obtained through the cluster analysis}

\begin{tabular}{|c|c|c|c|c|}
\hline Jihovýchod & Jihozápad & Moravskoslezsko & Severovýchod & Severozápad \\
\hline Strední Cechy & Strední Morava & Estonia & Dél-Alföld & Dél-Dunántúl \\
\hline Észak-Alföld & Észak-Magyarország & Közép-Dunántúl & Nyugat -Dunántúl & Basilicata \\
\hline Molise & Dolnoslaskie & Kujawsko-Pomorskie & Lódzkie & Lubuskie \\
\hline Opolskie & Podkarpackie & Pomorskie & Slaskie & Warminsko-Mazurskie \\
\hline $\begin{array}{l}\text { Wielkopolskie } \\
\text { Západné Slovensko }\end{array}$ & Zachodniopomorskie & Norte & Stredné Slovensko & Východné Slovensko \\
\hline \multicolumn{5}{|c|}{ GROUP 2: Regions with a weak economic and technological performance } \\
\hline Burgenland & Cyprus & Andalucia & Canarias (ES) & Castilla-la Mancha \\
\hline Castilla y León & Extremadura & Galicia & Illes Balears & Principado de Asturias \\
\hline Región de Murcia & Corse & Anatoliki Makedonia, Thr & Dytiki Ellada & Dytiki Makedonia \\
\hline Ionia Nisia & Ipeiros & Kentriki Makedonia & Kriti & Notio Aigaio \\
\hline Peloponnisos & Sterea Ellada & Thessalia & Voreio Aigaio & Calabria \\
\hline Campania & Puglia & Sardegna & Sicilia & Lithuania \\
\hline Latvia & Lubelskie & Malopolskie & Podlaskie & Swietokrzyskie \\
\hline Alentejo & Algarve & Centro (PT) & & \\
\hline \multicolumn{5}{|c|}{ jions with average economic and technological performance } \\
\hline Kärnten & Niederösterreich & Oberösterreich & Salzburg & Steiermark \\
\hline Tirol & Sachsen-Anhalt & Schleswig-Holstein & Aragón & Cantabria \\
\hline Cataluña & Comunidad Foral de Navar & Comunidad Valenciana & La Rioja & Pais Vasco \\
\hline Åland & Itä-Suomi & Aquitaine & Auvergne & Basse-Normandie \\
\hline Bourgogne & Bretagne & Centre & Champagne-Ardenne & Limousin \\
\hline Lorraine & Pays de la Loire & Poitou-Charentes & Ireland & Abruzzo \\
\hline Emilia-Romagna & Friuli-Venezia Giulia & Liguria & Marche & Provincia Autonoma Bolza \\
\hline Provincia Autonoma Trent & Toscana & Umbria & Valle d'Aosta/Vallée d'A & Veneto \\
\hline Mellersta Norrland & Norra Mellansverige & Småland med öarna & Slovenia & Northern Ireland \\
\hline \multicolumn{5}{|c|}{$\begin{array}{l}\text { GROUP 4: Advanced regions, with a certain industrial specialisation } \\
\text { Vorarlberq }\end{array}$} \\
\hline Vorarlberg & Région Wallonne & Vlaams Gewest & Baden-Württemberg & Bayern \\
\hline Hessen & Niedersachsen & Nordrhein-Westfalen & Rheinland-Pfalz & Saarland \\
\hline Thüringen & Alsace & Franche-Comté & Haute-Normandie & Nord - Pas-de-Calais \\
\hline Picardie & Rhône-Alpes & Lombardia & Piemonte & Drenthe \\
\hline Friesland & Limburg (NL) & Overijssel & Zeeland & East Midlands \\
\hline Eastern & North East & North West (including Me & Scotland & South West \\
\hline Wales & West Midlands & Yorkshire and The Humber & & \\
\hline GROUP 5: Innovative regi & ons, with a high level of $e$ & conomic and te & Pohpinis-sumi & Noord-Brahant \\
\hline Östra Mellansverige & & $\begin{array}{l}\text { Länsi-Suomi } \\
\text { Stockholm }\end{array}$ & $\begin{array}{l}\text { Pohjols-Suomı } \\
\text { Sydsverige }\end{array}$ & $\begin{array}{l}\text { Noord-Brabant } \\
\text { Västsverige }\end{array}$ \\
\hline \multicolumn{5}{|c|}{ GROUP 6: Capital-regions, with a certain specialisation in high value-added services } \\
\hline Berlin & Brandenburg & Mecklenburg-Vorpommern & Sachsen & Comunidad de Madrid \\
\hline Languedoc-Roussillon & Midi-Pyrénées & Provence-Alpes-Côte d'Az & Attiki & Közép-Magyarország \\
\hline & Flevoland & Gelderland & Mazowieckie & Lisboa \\
\hline \multicolumn{5}{|l|}{ Bratislavský kraj } \\
\hline $\begin{array}{l}\text { GROUP 7: Innovative capi } \\
\text { Wien }\end{array}$ & $\frac{\text { tal-regions, specialised in }}{\text { Région de Bruxelles-Capi }}$ & $\begin{array}{l}\text { high value-added service } \\
\text { Praha }\end{array}$ & Bremen & Hamburg \\
\hline Île de France & $\begin{array}{l}\text { Reglon de Bruxelles-Capl } \\
\text { Luxembourg (Grand-Duché) }\end{array}$ & Groningen & Noord-Holland & Utrecht \\
\hline Zuid-Holland & London & South East & & \\
\hline
\end{tabular}

In this typology, the principal components that distinguish the groups of regions are related to economic and technological development on the one hand, and to sectoral specialisation on the other. In the taxonomies offered by other authors the features that determine the groups of regions differ. In some typologies only the technological capacity and development are considered (Ecotec 2005, Hollanders 2003, Hollanders 2007). In others, technological capacity, 
development and sectoral specialisation are considered (Brujin and Lagendijk 2005 and Muller and Nauwelaers 2005). In some of them, apart from economic and technological development and sectoral specialisation, the evolutionary tendency of these factors is taken into account (Clarysse and Muldur, 1999). Finally, in some of the typologies (Martínez-Pellitero, 2007) the main explanatory factor of the regional groups is the regional size, included in the "regional environment factor". This occurs because the value of some regional variables such as GDP, population, employment and so on has not been divided by the regional size. The typology presented in this paper is close to those that take into account both sectoral specialisation and economic and technological development. That is the case, especially, of the typology proposed by Muller and Nauwelaers, although this was elaborated only for the most recent members of the European Union.

Finally, we have noted the existence of other typologies arising from theoretical frameworks and confronted with case studies. Some of these (for example, those of Cooke and Asheim) are not directly comparable with that presented in this paper, because they consider entrepreneurial innovation types and the relationships between agents and governance. In other typologies (Tödtling and Trippl), the categories of regions (peripheral, metropolitan and old industrial) are linked with the ones obtained in this paper. Peripherality, industrial weight and service and urban development are distinctive features of the groups that we have obtained.

Following this presentation and comparison of regional typologies for the EU25 , we will analyse in-depth the different groups achieved.

\section{Type 1. Restructuring industrial regions with strong weaknesses}

This group is formed by 31 regions, most of them (90\%) belonging to the EU10. These regions have low levels of income, much lower than the EU-25 average. On average, the weight of the manufacturing sector is high (with some exceptions, such as Estonia), and there are low levels in tertiary education, life- 
long learning, accessibility, human resources in science and technology and expenditures on R\&D.

These regions could benefit from the delocalisation processes that are taking place in the most developed areas of EU-15. As Muller and Nauwelaers (2005) have highlighted, their challenge is to take advantage of exogenous development opportunities (international foreign investment and relocation of industrial activities from the rest of the $\mathrm{EU}$ ) in order to create internal forces to support a sustainable economic development. A first step in this direction should be the rationalisation of the industrial facilities in order to optimise cost structures. Following Porter (1990 and 1998) we can conclude that these regions are in a development stage based on the low cost of labour. They should advance to the next competitive stage based on efficiency and investment, depending among other factors on the absorptive, adaptive and diffusion capacity of technologies developed outside. In order to achieve this goal they should link foreign investment to the regional economy by proper cluster initiatives, so that the regional economic tissue could benefit from that foreign investment. Otherwise, foreign investments will not be anchored to the region and its attractiveness based on lower labour costs will disappear in the future.

Besides, measures that may enhance the absorptive capacity of these regions should be taken in order to improve their situation in tertiary education, life-long learning, etc.. As Sterlacchini (2006) or Clarysse and Muldur (1999) show, the bare augmentation of R\&D expenditures might not generate the effects desired in the less developed regions because they do not have the necessary absorptive capacity to take advantage of R\&D activities and of knowledge diffusion activities. In some regions it is necessary to develop a certain social capability as a result of increases in the levels of productivity and per capita income rather than increases of R\&D intensity and number of patents. This means that in the less developed regions, the policy stress should be put not on measures that simply stimulate R\&D activities, but in policies oriented to increment that absorptive capacity. We cannot forget that companies are the ones who innovate and not policies by themselves. That is why policies that 
enhance investments and the creation of technological demand by firms are also needed.

Type 2. Regions with a weak economic and technological development

The main feature that defines the majority of the 38 regions of this group is the low level of economic and technological development. The per capita income of these regions is lower than the EU-25 average (with some exceptions, such as Balearic Islands). The same happens with R\&D intensity, tertiary education, employment rate, life-long learning and human resources in science and technology. Besides, these regions have a low population density and low accessibility. With some exceptions, the least developed regions of EU-25 are in this group. The weight of industry is very light in this group: some regions rely on the service sector (mainly tourism) while others rely on agriculture.

These regions should focus their efforts on achieving a critical mass of technological capacity in those areas where their economy could exploit some competitive advantages. These areas could vary from region to region, depending on the regional productive specialisation. The indicators regarding R\&D show us that the regional innovation systems of these territories are at a very early stage or just do not exist. A first step to foster development could be to improve the education levels from secondary education to tertiary education, promote life-long learning, enhance accessibility with the rest of Europe and set the base of an RIS that could absorb, adapt and transfer technology and knowledge from the rest of the world to the region. We should not ignore the fact that, first, these regions need to develop a certain absorptive capacity. This capacity will have a bigger impact in GDP growth than R\&D expenditures or patents. In peripheral regions like the ones of this type, the R\&D activities done by universities have a more positive impact and, if this R\&D has a more applied focus, it may compensate the lack of private R\&D (Bilbao-Osorio and Rodríguez- Pose, 2004). Although Italy, Greece, Spain and Portugal have been EU members for many years, plenty of their regions still have a level of development below the EU-25 average. This situation points out the persistent weaknesses of their productive systems, weaknesses that have not been 
solved by the development policies adopted up to the present time (Clarysse and Muldur, 1999).

Type 3. Regions with average economic and technological performance

This group of regions is the biggest in the typology: up to 45 of the EU-25 regions. The centroid of this group in figure 2 is very close to the central point of the map. This fact implies an economic and technological development close to the average values of EU-25. However, the performance of these regions is heterogeneous. The main factor in grouping this type 3 is the economic and technological development, shared by all of them. Regarding to productive structure, the variability among regions is wider. Some regions have a certain industrial specialisation (Basque Country, Lorraine), while others are specialised in services (Salzburg) or in advanced agriculture (Abruzzo). All regions of this group belong to EU-15, with the exception of Slovenia. The economic and technological development of this region since the beginnings of 1990s has been remarkable and has put Slovenia with the average regions of the EU-25.

The challenge for these regions is to invest and boost their absorptive and knowledge creation capabilities (the majority of them have an average value on technological inputs). Secondly, they should articulate harmoniously their RIS, incrementing the quality and quantity of the relationships between their agents, so that the R\&D investment could reflect in greater levels of technological results (innovations, patents). Due to the heterogeneity of this group, the economic structure of each region should be taken into account when reinforcing each particular RIS. The policy measures that should be applied (development of non-technological innovations, patents, research done by the university ...) will vary according to the economic and entrepreneurial structure of the region. Moreover, models of more advanced regions that could be a referenced to compare and learn will differ. Following this idea, regions with a strong industrial specialisation should consider groups 4 and 5, while those with a more diverse economic structure or specialised in services should consider groups 6 and 7. For instance, the Basque Country (situated in this type 3, but 
located close to type 4), a region specialised in metal industries, such as automobile industry and machine tools, should study development models of regions such as Baden-Württemberg, located in group 4. Both regions have a similar sectoral specialisation, but the technological development, per capita income and productivity are much higher in Baden-Württemberg than in the Basque Country. This idea does not mean that each region should abandon the aim of developing a unique proposition of value. Together with this search for differentiation, each region should compare with others of similar characteristics, especially with the ones situated in the next innovative and competitive stage of development. As a result, ways of improving and compensating weaknesses may be found.

\section{Type 4. Advanced regions, with a certain industrial specialisation}

This group is formed by 33 regions (all belonging to the EU-15), with a good performance in economic development and a certain industrial specialisation. Many regions of this group have traditionally had a strong industrial sector. These regions have had the ability to base their industry in medium-high and high-tech manufactures, with a strong development of R\&D activities (BadenWürttemberg). Alternatively, other regions have shifted their industrial activities towards new growing sectors. That is the case of Scotland with biosciences, helped by a well developed university system. On average, these regions have a high level of accessibility, high population density and high R\&D expenditures, shared by all agents of their RIS.

In these territories the development of innovation policies centred in the productive sectors where the regional economy has its main competitive advantages is very important. In many cases, regions will have a synthetic knowledge base (for example, the aforementioned Baden-Württemberg). Others could have an analytic knowledge base (for instance, Scotland). As Asheim and Gertler (2005) have shown, the combination of tacit/codified knowledge, organisations and institutions (university, R\&D units), qualification and capabilities (education, continuous training, and experience) and innovation types (incremental or radical, spin-offs, etc.) vary according to the knowledge 
base. This fact should be taken into account by policy makers when designing innovation policy. The creation and diffusion of knowledge through the industrial tissue will require the strengthening of all RIS components and the collaboration between them. Nonetheless, the kind of components and the collaboration that should be encouraged between them will vary according to the regional productive structure. At the same time, there is a need to improve relationships with organizations and components of other innovation systems, in order to enhance the knowledge base of local agents and also to avoid lock-in situations (Bathelt et al. 2003). The clusterisation of productive activities could be a key element to fulfil all the aforementioned objectives. However, the final objective of increasing the regional competitive advantage may require that some productive activities (the ones with less added value) will be delocalised to other regions (in some cases, regions of the new Member-states, for example group 1 regions) that possess a basic industrial framework and qualified labour combined with low costs. In this kind of situation both the region that receives the direct investment and the one that sends it should benefit from the process.

Type 5. Innovative regions, with a high level of economic and technological development

This group, the smallest one, is composed by 10 regions of northern Europe (especially of the Scandinavian countries). The main feature of this group is its high level of economic and technological development, which locates them at the European vanguard in spite of their geographical position, very far from the centre of Europe. These regions have high educational levels and life-long learning is widespread. Expenditures on R\&D activities are very high, as is patent creation. On average, the RIS is well balanced between its main agents or components (firms, university and public administration).

In this group there are capital-regions with a diversified economic structure that includes high-tech services and financial and business services, such as Stockholm or Denmark. On the other hand there are also regions specialised in medium-high and high-tech manufactures, such as Pohjois-Suomi or Noord Brabant. The majority of the Scandinavian regions of this group have a 
population density below the EU-25 average. This fact has not impeded their economic and technological development.

The challenge for these regions should be to internationalise their RIS, so that agents of these RISs could take part (or lead) international innovation networks, and firms could achieve enough knowledge and productivity to compete in globalised markets based on sophisticated demand. At the same time, these regions should enhance the diffusion of innovation to all economic sectors, including the so-called traditional sectors.

Type 6. Capital-regions, with a certain specialisation in high value-added services

This group of 16 members is composed mainly by regions that encompass national capitals: Berlin, capitals of Southern Europe (Madrid, Rome, Athens, and Lisbon) and capitals from Central and Eastern Europe. The first ones have been denominated by the State of European Cities Report of the European Commission (2007) as "established capitals": cities located in the upper position of national cities, with a diversified economic base and concentration of wealth. In the cases of Rome and Berlin their position is less dominant in their national contexts. Madrid, Lisbon and Athens, however, have a level of per capita income much higher than their national averages. They have a great importance culturally, politically and economically and act as attractors of young qualified professionals from the rest of the country and even from the rest of the world. The same report has classified the capitals from Central and Eastern Europe as "re-invented capitals", considered as champions of the economic transition and engines of the economic activity of the new Member-States. Those cities have taken advantage of the deep restructuring processes that they have gone through, as it is shown by their remarkable levels of economic growth with no population increment. These reinvented capitals show much higher levels of per capita income and growth than the national average, they are the engines of their national economies and contribute positively to the general competitiveness of Europe. 
Together with economic development, the regions of this group have reached a level of technological development above the EU-25 average. This position is due to the concentration of national public research facilities and the concentration of the headquarters and R\&D activities of big companies (nationals and especially foreign companies) located in each country. In addition to the aforementioned capital-cities, in this group there are other regions with a high concentration of private and public research activities and a high level of economic development. In general, their population density is also high, with high levels of income, education and human resources in science and technology. They tend to specialise in high-tech services and financial and business services.

Regarding policy issues, the challenge for this group is to enhance the R\&D conducted by companies and achieve a true transmission of knowledge and technology between public research facilities, universities and firms. This interaction between the RIS agents is especially important due to the high concentration of public research infrastructure in these regions. The regions encompassing reinvented capitals should continue improving their economic growth, avoiding a mere conversion into established capitals, in order to advance to the next stage: "knowledge hubs". Besides, the established capitals should move beyond their current and comfortable position based on the concentration of economic and political power, reinforcing their international connectivity and trying to deepen in knowledge intensive activities and high-tech services.

Type 7. Innovative capital-regions, specialised in high value-added services

In this group we can find the most developed capital-regions in the EU-25 (Vienna, Paris, Brussels, Luxemburg, London, Prague and Amsterdam) and some other regions with important cities that have turned into "knowledge hubs" or "national service hubs", following the classification of the State of European Cities Report. As a whole, this group could be considered as Functional Urban Regions of Capitals (Cheshire and Hay, 1989). That is the case of London and the South-East in the UK; Zuid Holland, Noord Holland and Utrecht in Holland; 
and Hamburg and Bremen in Germany. On average, these regions have high levels of income, tertiary education, life-long learning, accessibility, population density and patents. At the same time, R\&D expenditures are very high, concentrated mainly in the university and the public sector. Their sectoral specialisation is in high-tech services and financial and business services, all of them acting as a support to innovation activities. The capital-regions of this group concentrate a large part of the public research infrastructure of their countries, and also the most developed university systems. The inclusion of Prague in this group is a result of the economic growth of the region since the early 90s, the concentration of technological infrastructures in the former Republic of Czechoslovakia and the location of foreign companies.

These regions should encourage the investment in technological and nontechnological innovations, internationalise their RIS and attract talent. In this way, the agents of their innovation systems could interact in global and advanced knowledge networks, easing the creation and diffusion of first class knowledge at global standards. This global interaction should take into account the needs of firms located in these territories and encourage their effective integration in global and excellent innovation networks.

\section{Conclusions}

The objective of this study was to provide a typology of regions capturing the diversity of regional innovation systems across the EU-25, and therefore help design better adapted policies to the characteristics and needs of each region. In addition, this research will contribute to the relatively scarce empirical literature on the study of the interrelations between innovation and the territory, i.e. regional innovation systems, from a statistical point of view, with the use of aggregated data from secondary sources.

Our research covers 186 regions of the EU-25 and it includes twenty nonsynthetic indicators from the REGUE data set, and a peripherality index calculated by Schürmann and Talaat (2000). The selected twenty-one indicators characterise the ability of a region to generate and absorb knowledge, and their 
capacity to transform R\&D into innovation and economic growth, e.g. their social and economic characteristics.

Based on a cluster analysis following an initial principal components analysis, the following key findings are identified:

- There are two main factors that characterise EU-25 regions: their level of economic-technological development and their sectoral specialisation. The typologies that do not take this last factor into account ignore a key element that is decisive for the economic development of a region and for the design and implementation of adequate policies to strengthen its regional innovation system.

- Accessibility is another key element that affects positively the economic and technological capacity of a region, and therefore should not be neglected. Sweden and Finland, as exceptions to the rule, show that geographical peripherality is not always incompatible with high economic and technological development levels.

- The economic and technological development factor identified in our research seems in line with the theory of the stadiums of competitive development proposed by Porter (1990). At the rear of the spectrum are regions with a development model based on low costs of production factors (whether labour force, in the industrial regions of the EU-10; or natural resources, in the less developed regions of the EU-15). In the middle are regions that compete on the basis of investment and efficiency. They are capable of absorbing and adapting foreign technologies, but have limited ability to generate their own. Finally, at the top are regions that compete in the stadium of innovation, thanks to an economic specialisation in either high and medium-high manufacturing sectors or in high-tech and knowledge-intensive services.

- There is a clear differentiation between regions with a notable industrial profile and regions with a strong either agricultural or service sector, 
distinguishing, in the latter, different types. Due to these production and sectoral specialisations, the regions would create and rely on different knowledge bases.

- Less developed regions, within different groups, should aim at policies allowing them to migrate from the lower competitive and innovation stadium to the most advanced one. In order to do so, they should be aware of their productive and knowledge bases. Our typology could serve as a guideline for regions to identify other regions in higher stages of competitive and innovative stadium with similar profiles, from which to learn and benchmark. Best practices in these regions should be analysed in order to identify the possibility of implementing similar policies in their territories. A warning note must be stressed at this point, as copying policies in could turn into negative results. Policies should be contingent to the level of development of each region and the specific characteristics of each context, including its restrictions and weaknesses. As with an enterprise, each region must seek its unique value proposition that takes into account its assets and liabilities, its legacy, its "genetic code" (Azua 2000).

- In the lowest stage of economic and technological development there are two types of regions with different challenges: the less developed nonindustrial regions in Southern Europe, and most of the regions belonging to the new accession countries, many of them with an industrial economy. For the case of the Southern European regions, decades of national targeted policies and EU structural funds have not been able to reverse this adverse situation. This fact raises questions about the adequacy of these policies. With regards Central and Eastern European countries, fifteen years after the collapse of communism, their regions, with some exceptions, still form a homogeneous block. This finding suggests that reforming regional innovation systems is a lengthy, complex and resource intensive process that cannot be carried out over night. Only the capital city regions of these countries have been able to "re-invent" themselves and manage to reach a superior competitive and innovation stage. 
- In order to foster the economic and technological profile of these less developed regions, the mere increase of R\&D inputs and patent production may not the best means to increase their capacity to absorb and adapt knowledge. Rather, overall increases in their productivity growth and income per capita levels may yield better results. Therefore, the primary objective of their development policies should focus on increasing their absorptive capacity, tackling their weaknesses in education, life-long learning and other negative characteristics of these regions. Moreover, both the less developed regions of the EU-15 and the regions of the accession countries are characterised by a poor degree of accessibility, which should also be corrected.

- The regions of the accession countries could benefit from the re-localisation of industrial activities within the EU. This could trigger an economic and productivity growth process resulting in an enhanced capacity to absorb and adapt knowledge. At the same time, more advanced regions in the EU-15 could benefit from specialising in more knowledge intensive activities. However, there is the risk that these foot-loose companies may decide to relocate after a few years in other areas where competitive costs become more advantageous. Therefore, cluster policies that anchor these companies to the territory and that allow local firms to create linkages with the newcomers should be favoured at the same time. Other policies, such as educational or research policies, addressing the local weaknesses of the regional innovation system should be equally implemented. Regional actors should get involved in EU learning networks in order to strengthen the technological catch-up resulting from such relocations.

- The processes of industrial relocation could complement the role that the "re-invented capitals" are playing as strong engines of economic growth (European Commission 2007), and contribute to a more territorial balanced economic and technological development. These capital regions have managed to exploit the opportunities accruing from the deep restructuring of their economies and have benefited from the concentration of R\&D expenditure, essentially public, but also private. 
- The less developed regions of Southern Europe also need to increase their capacity to absorb and adapt knowledge, with measures like those mentioned above. However, it should be noted that due to their sectoral structure and higher wages, it is unlikely that they can benefit from the industrial relocation phenomenon. These regions must rely more on their endogenous capabilities and on fostering the benefits associated with their local production specialisation, developing a regional innovation system adapted to it.

- With regards to the other regions, as already mentioned, they should take into account their stage of competitive development, production specialisation and knowledge base in order to implement "migration" strategies to higher stages. In the case of those regions in intermediate stages, they should pay particular attention to the development of harmonious strategies that favour the interactions among all agents in the innovation system. They should stimulate the technological and nontechnological innovation investments, as well as the relationships with organisations and agents of other systems, nurturing new knowledge and avoiding "lock in" processes. In some cases, progress may come from deepening the innovative activities in sectors where the region has traditionally been involved (e.g. Baden-Württemberg), and in some other cases, embarking in new growth sectors (e.g. Scotland). In all cases, these regions must follow strategies based on their competitive advantages, and position themselves as poles of excellence.

Finally, the capitals or main cities within many regions seem to predetermine the type and dynamism of the whole regional innovation system. As a result, it becomes clear that the present classification of regional innovation systems could and should be complemented with a typology of cities ("capital city", "reinvented capitals", "established capitals", "knowledge hubs", etc). This classification, which would benefit from larger available data, would help identify and understand the challenges and opportunities that regions face and may face in the future. 
TABLE 1: REVIEW OF TYPOLOGIES OF EUROPEAN REGIONS OBTAINED FROM SECONDARY SOURCES

\begin{tabular}{|c|c|c|c|c|c|}
\hline AUTHORS & CONSIDERED REGIONS & STATISTICAL TECHNIQUE & DATASOURCE & CONSIDERED VARIABLES & OBTAINED TYPOLOGY \\
\hline Clarysse and Muldur (1999) & $\begin{array}{l}\text { EU-15: NUTS } 1 \text { (BE, DE, } \\
\text { UK) and NUTS } 2 \text { (rest) }\end{array}$ & Factorial and cluster & Eurostat Regions & $\begin{array}{l}\text { GDP per capita, agricultural employment, total R\&D, } \\
\text { patents, GDP variation, patents variation, unemployment } \\
\text { variation }\end{array}$ & $\begin{array}{l}6 \text { groups: industry leaders, } \\
\text { clampers-on, slow grower, } \\
\text { economic catcher-up, lagers } \\
\text { behind }\end{array}$ \\
\hline ECOTEC (2005) & $\begin{array}{l}\text { EU-27: NUTS } 2 \text { (most) } \\
\text { and NUTS } 1 \text { (if NUTS } 2 \\
\text { not available) }\end{array}$ & $\begin{array}{l}\text { Two different methods: (1) Z- } \\
\text { score analysis; (2) three cluster } \\
\text { analysis: rescaled data for four } \\
\text { individuals, two compound } \\
\text { indicators and average of the } \\
\text { six indicators }\end{array}$ & $\begin{array}{l}\text { Eurostat Regions (Supplemented } \\
\text { with contacts at national statistics } \\
\text { agencies) }\end{array}$ & $\begin{array}{l}3 \text { indicators of R\&D: R\&D expenditure, R\&D staff, HRST } \\
\text { core. And } 3 \text { indicators of innovation: Employment } \\
\text { medium and high-tech manufacturing, employment in } \\
\text { knowledge-intensive services, population with tertiary } \\
\text { education }\end{array}$ & $\begin{array}{l}\text { (1) Z-score analysis: } 5 \text { types of } \\
\text { areas: lack of capacity, average } \\
\text { capacity, rich innovation, rich R\&D } \\
\text { and knowledge centres. (2) } \\
\text { Cluster analysis: } 5 \text { clusters in } \\
\text { each of the three analyses }\end{array}$ \\
\hline Hollanders (2003) & $\begin{array}{l}\text { EU-15: } 171 \text { regions (NUTS } \\
1 \text { and 2) }\end{array}$ & Cluster & $\begin{array}{l}\text { Eurostat Regions and CIS II } \\
\text { innovation survey) }\end{array}$ & $\begin{array}{l}14 \text { variables: tertiary education, life-long learning, } \\
\text { medium and high tech manufacturing employment, } \\
\text { employment in knowledge-intensive services, public R\&D } \\
\text { expenditure, business R\&D expenditure, patents, high- } \\
\text { tech patents, innovative companies in manufacturing, } \\
\text { innovative companies in services, innovation costs in } \\
\text { manufacturing, innovation costs in services, sales of } \\
\text { products new to the firm in manufacturing and per capita } \\
\text { GDP }\end{array}$ & $\begin{array}{l}6 \text { groups: } 2 \text { high-tech groups with } \\
3 \text { regions each; and } 4 \text { others with } \\
\text { a much higher number of regions, } \\
\text { especially those located close to } \\
\text { the EU average or below this }\end{array}$ \\
\hline Brujin and Lagendijk (2005) & EU-15: NUTS 2 & Factorial and cluster & Eurostat Regions & $\begin{array}{l}\text { Level and variation of: per capita GDP, GDP per } \\
\text { employee, workforce with tertiary education, students of } \\
\text { tertiary education, R\&D expenditure, employment in high- } \\
\text { tech manufacturing, employment in technology-intensive } \\
\text { services, employment in life-long learning, patents }\end{array}$ & $\begin{array}{l}6 \text { groups: with very strong } \\
\text { diversified position, with strong } \\
\text { position in knowledge-intensive } \\
\text { services, with strong growth in } \\
\text { knowledge-intensive services, } \\
\text { with a strong position in high-tech } \\
\text { sectors, with strong growth in } \\
\text { high-tech sectors and those who } \\
\text { stay behind }\end{array}$ \\
\hline $\begin{array}{l}\text { Muller and Nauwelaers } \\
\text { (2005) }\end{array}$ & EU-12 (enlargement) & $\begin{array}{l}\text { Double factorial: (1) with five } \\
\text { variables included in } \\
\text { knowledge creation; (2) with } \\
\text { the factor of knowledge } \\
\text { creation and the } 20 \text { remaining } \\
\text { variables }\end{array}$ & $\begin{array}{l}\text { Eurostat Regions; PATDPA own } \\
\text { holdings, SCI, eEuropesources by } \\
\text { Fraunhofer ISI; and Merit }\end{array}$ & $\begin{array}{l}25 \text { variables arranged in five groups: knowledge creation, } \\
\text { knowledge absorption, diffusion of knowledge, demand } \\
\text { of knowledge and governance }\end{array}$ & $\begin{array}{l}5 \text { groups: capitals, with tertiary } \\
\text { growth potential, qualified } \\
\text { manufacturing platforms, with } \\
\text { industrial challenges, agricultural } \\
\text { laggards }\end{array}$ \\
\hline Hollanders (20007) & $\begin{array}{l}\text { EU-25: } 206 \text { regions NUTS } \\
1 \text { and } 2\end{array}$ & Hierarchical clustering & Eurostat Regions & $\begin{array}{l}6 \text { indicators: HRST, life-long learning, public R\&D } \\
\text { expenditure, business R\&D expenditure, employment in } \\
\text { medium and high-tech manufacturing, employment in } \\
\text { high-tech services, patents }\end{array}$ & $\begin{array}{l}12 \text { groups for innovation } \\
\text { performance }\end{array}$ \\
\hline Martínez-Pellitero (2007) & EU-15: NUTS 1 and 2 & Factorial and cluster & $\begin{array}{l}\text { IAIF-RIS (EU) base made from } \\
\text { Eurostat Regions (with estimates } \\
\text { of missing values), supplemented } \\
\text { by Infostate and Economic } \\
\text { Freedom }\end{array}$ & $\begin{array}{l}29 \text { variables, grouped into } 6 \text { factors: national } \\
\text { environment, regional environment, innovative } \\
\text { companies, universities, public administration and } \\
\text { demand }\end{array}$ & $\begin{array}{l}10 \text { groups, grouped in turn by the } \\
\text { author into three categories: } \\
\text { atypical (for highlighting positively } \\
\text { in some of the factors), } \\
\text { intermediate and least developed }\end{array}$ \\
\hline
\end{tabular}




\section{TABLE 2: INDICATORS USED FOR THE ELABORATION OF THE TYPOLOGIES OF REGIONS}

\begin{tabular}{|c|c|c|c|c|}
\hline Indicator & Code & Securing & Numerator & Denominator \\
\hline $\begin{array}{l}\text { Per capita income (PPP) } \\
\text { Employment rate (\%) } \\
\text { Productivity (PPP) }\end{array}$ & $\begin{array}{l}\text { pib_pc2 } \\
\text { templeo } \\
\text { pib_emp2 }\end{array}$ & \begin{tabular}{|l|} 
Direct \\
Direct \\
Direct
\end{tabular} & $\begin{array}{l}\text { GDP } \\
\text { Employment } \\
\text { GDP }\end{array}$ & \begin{tabular}{|l|} 
Population \\
Population \\
Employment
\end{tabular} \\
\hline Neperian logarithm of the population density (inhabitants per $\mathrm{km}^{2}$ ) & logdens & $\log$ (dens.) & Population & Area of the region in $\mathrm{km}^{2}$ \\
\hline Peripherality index & Peripherality index & Direct & & Accessibility index \\
\hline $\begin{array}{l}\text { Employment in primary sector (\%) } \\
\text { Industrial employment (\%) }\end{array}$ & $\begin{array}{l}\text { ear } \\
\text { eirr }\end{array}$ & \begin{tabular}{|l} 
(ea)*100/(employment) \\
(ei1)*100/(employment)
\end{tabular} & $\begin{array}{l}\text { Employment in agriculture, livestock and fishing } \\
\text { Industrial employment (without construction) }\end{array}$ & $\begin{array}{l}\text { Employment } \\
\text { Employment }\end{array}$ \\
\hline Employment in business and financial services (\%) & es2r & (es2)*100/(employment) & $\begin{array}{l}\text { Employment in financial intermediation, real estate services, rents and } \\
\text { other business services } \\
\text { Employment in chemistry (NACE24), machinery (NACE29), office }\end{array}$ & Employment \\
\hline Employment in medium-high and high technology manufacturing sector & et.m1r & (et.m1)*100/[(ei1)+(es)] & $\begin{array}{l}\text { equipment (NACE30), electrical equipment (NACE31), } \\
\text { telecommunications equipment (NACE32), precision instruments } \\
\text { (NACE33), automobiles (NACE34), aircraft and other transportation } \\
\text { (NAFF35) }\end{array}$ & $\begin{array}{l}\text { Industrial employment (without } \\
\text { construction) and services }\end{array}$ \\
\hline Employment in high-tech services & se_kis_htr & (se_kis_ht)*100/[(ei1)+(es)] & $\begin{array}{l}\text { Employment in post and telecommunications (NACE64), information } \\
\text { technology and software (NACE72) and R\&D services (NACE73) }\end{array}$ & $\begin{array}{l}\text { Industrial employment (without } \\
\text { construction) and services }\end{array}$ \\
\hline Youth educational level (\%) & educ_terr & (educ.ter)*100/(reg_d2avg) & Students with 5 and 6 ISCED levels & Population 20-24 years \\
\hline Population 25-64 with tertiary education (\%) & pnive5y6r & (pnive5y6)*100/(pob25-64) & Population 25-64 years with 5-6 ISCED levels & Population 25-64 years \\
\hline $\begin{array}{l}\text { Population 25-64 participant in life-long learning }(\%) \\
\text { Human resources in science and technology core }(\%)\end{array}$ & $\begin{array}{l}\text { plllr } \\
\text { hrstcr }\end{array}$ & $\begin{array}{l}(\text { pllll)*100/(pob25-64) } \\
\text { (hrstc)*100/(pt) }\end{array}$ & $\begin{array}{l}\text { Population 25-64 years participating in life-long learning } \\
\text { HRST core }\end{array}$ & $\begin{array}{l}\text { Population 25-64 years } \\
\text { Population }\end{array}$ \\
\hline $\begin{array}{l}\text { Human resources in science and technology core (\%) } \\
\text { Total R\&D expenditure (\% of GDP) }\end{array}$ & $\begin{array}{l}\text { hrstcr } \\
\text { g_pib_t }\end{array}$ & 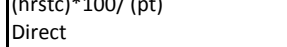 & $\begin{array}{l}\text { HRST core } \\
\text { Total R\&D expenditure }\end{array}$ & $\begin{array}{l}\text { lopulation } \\
\text { GDP }\end{array}$ \\
\hline Government R\&D expenditure (\% of GDP) & g_pib_ap & Direct & Governemt R\&D expenditure & GDP \\
\hline Higher education R\&D expenditure (\% of GDP) & g_pib_es & Direct & Higher education R\&D expenditure & GDP \\
\hline Business R\&D expenditure (\% of GDP) & g_pib_em & Direct & Business $R \& D$ expenditure & GDP \\
\hline R\&D expenditure per ooccupied in R\&D (PPP) & gidpc & $($ g_pib_t $) * 1000000 /\left(\left(p \_t\right.\right.$ _hc $)$ & R\&D expenditure & Personnel in R\&D (headcounts) \\
\hline EPO patents (million people) & paten_pc & Direct & Patents filed at the EPO, for year of priority, appointed to the inventor & Total population (million) \\
\hline High-tech EPO patents (million people) & pat_ht_p & Direct & Patents filed at the EPO, for year of priority, appointed to the inventor & Total population (million) \\
\hline
\end{tabular}


TABLE 3: INDICATORS EMPLOYED BY THE TYPOLOGIES OF EUROPEAN REGIONS 


\begin{tabular}{|c|c|c|c|c|c|c|c|c|}
\hline & $\begin{array}{l}\text { Clarysse and } \\
\text { Muldur (1999) }\end{array}$ & $\begin{array}{l}\text { Hollanders } \\
\text { (2003) }\end{array}$ & $\begin{array}{c}\text { Bruijn and } \\
\text { Lagendijk (2005) }\end{array}$ & $\begin{array}{c}\text { Muller and } \\
\text { Nauwelaers (2005) }\end{array}$ & $\begin{array}{l}\text { Ecotec } \\
(2005)\end{array}$ & $\begin{array}{l}\text { Hollanders } \\
\text { (2007) }\end{array}$ & $\begin{array}{l}\text { Martinez-Pelletero } \\
(2007)\end{array}$ & $\begin{array}{c}\text { This work } \\
(2008)\end{array}$ \\
\hline Number of indicator & 7 & 13 & 14 & 25 & 10 & 7 & 29 & 21 \\
\hline \multirow{4}{*}{$\begin{array}{l}\text { Per capita GDP } \\
\text { GDP per worker } \\
\text { Unemployment rate } \\
\text { Employment rate }\end{array}$} & $\bar{x}$ & $x^{1}$ & & $x$ & & & $x$ & $x$ \\
\hline & & & & & & & $x$ & $x$ \\
\hline & $x$ & & & $x$ & & & & \\
\hline & & & & & & & $x^{8}$ & $x$ \\
\hline \multirow{17}{*}{$\begin{array}{l}\text { GDP } \\
\text { Gross Added Value } \\
\text { Compensations of employees } \\
\text { GFCF per worker } \\
\text { Population density } \\
\text { Accessibility index } \\
\text { Venture Capital } \\
\text { Technology diffusion infrastructure } \\
\text { Scientific parks } \\
\text { Business innovation centres } \\
\text { Universities and public research institutes } \\
\text { Participation in European Programs } \\
\text { Broadband penetration } \\
\text { Firms using e-Administration } \\
\text { Firms using e-Banking } \\
\text { Web presence in the region } \\
\text { Households using www. }\end{array}$} & & & & & & & $x$ & \\
\hline & & & & & & & $x$ & \\
\hline & & & & & & & $x^{8}$ & \\
\hline & & & & & & & $x^{8}$ & \\
\hline & & & & $x$ & & & $x^{8}$ & $x$ \\
\hline & & & & & & & & $x$ \\
\hline & & & & & & & $x^{y}$ & \\
\hline & & & & $x$ & & & & \\
\hline & & & & & $x$ & & & \\
\hline & & & & & $x$ & & & \\
\hline & & & & & $x$ & & & \\
\hline & & & & $x$ & & & & \\
\hline & & & & & & & $x$ & \\
\hline & & & & $x$ & & & & \\
\hline & & & & $x$ & & & & \\
\hline & & & & $x$ & & & & \\
\hline & & & & $x$ & & & & \\
\hline \multirow{9}{*}{$\begin{array}{l}\text { Employment in agriculture, livestock and fishing } \\
\text { Industrial employment } \\
\text { Employment in business and financial services } \\
\text { Employment in medium and high-tech services } \\
\text { Employment in hig-tech services } \\
\text { Students in tertiary education } \\
\text { Research students } \\
\text { Population 25-64 with tertiary education } \\
\text { Population 25-64 with secondary education }\end{array}$} & $x$ & & & $x$ & & & & $x$ \\
\hline & & & & $x^{5}$ & & & & $x$ \\
\hline & & & & & & & & $x$ \\
\hline & & $x$ & $x^{2}$ & & $x$ & $x$ & & $x$ \\
\hline & & $x$ & $x^{3}$ & $x$ & $x$ & $x$ & & $x^{13}$ \\
\hline & & & $x$ & & & & & $x^{14}$ \\
\hline & & & & & & & $x$ & \\
\hline & & $x$ & $x^{4}$ & $x$ & $x$ & & & $x$ \\
\hline & & & & $x$ & & & & \\
\hline \multicolumn{2}{|l|}{ Population 25-64 with secondary and tertiary education } & & & $x$ & & & & \\
\hline Life-long learning & & $x$ & $x$ & $x$ & & $x$ & & $\mathrm{x}$ \\
\hline HRST & & & & & $\mathrm{x}$ & $x$ & $x^{10}$ & $x$ \\
\hline R\&D personnel & & & & $x$ & $x$ & & & \\
\hline Business R\&D personnel & & & & & & & $x^{11}$ & \\
\hline Higher Education R\&D personnel & & & & & & & $x^{11}$ & \\
\hline \multirow{8}{*}{$\begin{array}{l}\text { Total R\&D expenditure } \\
\text { Public R\&D expenditure } \\
\text { Business R\&D expenditure } \\
\text { Hlgher Education R\&D expenditure } \\
\text { Government R\&D expenditure } \\
\text { R\&D expenditure per occupied person in R\&D } \\
\text { Expenditure on innovation in manufacturing } \\
\text { Expenditure on innovation in services }\end{array}$} & $x$ & & $x$ & $x$ & $x$ & & $x$ & $x$ \\
\hline & & $\mathrm{x}$ & & & & $x$ & & \\
\hline & & $x$ & & $x$ & & $x$ & $\mathrm{x}$ & $\mathrm{x}$ \\
\hline & & & & $\mathrm{x}$ & & & $x$ & $\mathrm{x}$ \\
\hline & & & & & & & & $\mathrm{x}$ \\
\hline & & & & & & & & $x$ \\
\hline & & $\mathrm{x}$ & & & & & & \\
\hline & & $x$ & & & & & & \\
\hline \multirow{7}{*}{$\begin{array}{l}\text { Domestic innovative SMEs } \\
\text { Innovative manufacturing companies } \\
\text { Innovative service companies } \\
\text { Sales new to the firm in manufacturing } \\
\text { Patents } \\
\text { High-tech patents } \\
\text { Publications }\end{array}$} & & & & & & & & \\
\hline & & $\mathrm{x}$ & & & & & & \\
\hline & & $x$ & & & & & & \\
\hline & & $x$ & & & & & & \\
\hline & $x$ & $x$ & $x$ & $x^{6}$ & & $x$ & $x^{12}$ & $x$ \\
\hline & & $x$ & & & $x$ & & $x^{12}$ & $x$ \\
\hline & & & & $x^{\prime}$ & & & & \\
\hline Var. of per capita GDP & $\mathrm{x}$ & & & & & & & \\
\hline Accumulated var. of GDP & & & & $x$ & & & & \\
\hline Var. of demographic density & & & & $x$ & & & & \\
\hline Var. of unemployment & $\mathrm{x}$ & & & & & & & \\
\hline \multicolumn{3}{|c|}{ Var. of employment in medium and high tech manufacturing } & $x$ & & & & & \\
\hline Var. of employment in high-tech services & & & $x$ & & & & & \\
\hline Var. of tertiary education & & & $x$ & & & & & \\
\hline Var. of life-long learning & & & $x$ & & & & & \\
\hline Var. of students in tertiary education & & & $x$ & & & & & \\
\hline Var. of R\&D expenditure & & & $\mathrm{x}$ & & & & & \\
\hline Var. of patents & $x$ & & $x$ & & & & & \\
\hline
\end{tabular}

X1: not used in RIS. Used to describe clusters of regions

$\mathrm{x} 2$ : employment in high-tech sectors

$\mathrm{x} 3$ : employment in knowledge intensive services

$\mathrm{x}$ : : employees with tertiary educational level

$x 5$ : employment in manufacturing

$x 6$ : patents inventors concentration

$x 7$ : two subtypes: concentration in life science and in nanosciences

x8: expressed without relativising: population, employment and GFCF.

x9: two subtypes: seed and startup, and development

x10: three subtypes: in services, in knowledge intensive services and in high-tech

x11: two subtypes: in number of people and in FTE

x12: two subtypes: per inhabitant and per working population

$x 13$ : in knowledge intensive

x14: two subtypes: population 25-64 and employees with upper secundary or tertiary educational level 


\section{BIBLIOGRAPHY}

Abascal Fernández, E.; Landaluce Calvo, M.I. (2002). Análisis Factorial Múltiple como técnica de estudio de la estabilidad de los resultados de un análisis de componentes principales. Qüestiió. Vol. 26, 1-2: 109-122.

Amin, A. and Cohendet, P. (1999). Learning and adaptation in decentralized business networks. Environment and Planning D: Society and Space n. 17: 87-104

Anderson, M. and Karlsson, C. (2004). Regional Innovation Systems in Small \& Medium-Sized Regions. A Critical Review \& Assessment. CESIS Electronic Working Paper Series n. 10.

Arundel, A.; Kanerva, M.; Cruysen, A. and Hollanders, H. (2007). Innovation Statistics for the European Service Sector. Pro Inno Europe INNO METRICS.

Asheim, B. (2007). Sistemas regionales de innovación y bases de conocimiento diferenciadas: un marco teórico analítico (pp. 65-89). In Buesa, M. and Heijs, J. (coord.) Sistemas regionales de innovación: nuevas formas de análisis y medición. Madrid: Fundación de las Cajas de Ahorros.

Asheim, B. and Gertler, M. (2005). The Geography of Innovation. Regional Innovation Systems (pp. 291-317). In Fagerberg, J. et al. (eds.) The Oxford Handbook of Innovation. Oxford: Oxford University Press.

Azua, J. (2000). Alianza coopetitiva para la nueva economía: empresas, gobiernos y regiones innovadoras. Madrid: McGraw-Hill.

Bathelt, H. (2003). Geographies of production: growth regimes in spatial perspective (I) innovation, institutions and social systems. Progress in Human Geography n. 27, 6: 763778.

Bathelt, H. (2004). Geographies of production: growth regimes in spatial perspective (II) knowledge creation and growth in clusters. Progress in Human Geography n. 29, 2: 204216.

Bathelt, H., Malmberg, A. and Maskell, P. (2003). Cluster and knowledge: local buzz, global pipelines and the process of knowledge creation. Progress in Human Geography n. 28 (1): 31-56. [DRUID Working Paper 2002-12].

Baumert, T. (2006). Los determinantes de la innovación. Un estudio aplicado sobre las regiones de la Unión Europea. Doctoral thesis, Universidad Complutense de Madrid. Downloadble from: http://www.ucm.es/bucm/cee/iaif

Bilbao-Osorio, B. and Rodríguez-Pose, A. (2004). From R\&D to Innovation and Economic Growth in the EU, Growth and Change Vol. 35, n. 4, 434-455.

Braczyk, H.J., Cooke, P. and Heidenreich, M. (1998). Regional Innovation Systems. The role of governances in a globalized world. London: UCL Press.

Bruijn, P. and Lagendijk, A. (2005). Regional Innovation Systems in the Lisbon Strategy. European Planning Studies Vol. 13, n. 8: 1153-1172.

Buesa, M.; Baumert, T.; Heijs, J.; and Martínez-Pellitero, M. (2003). Metodología y resultados del índice IAIF de la Innovación Regional. Madri+d n. 16. Downloadble from: www.madrimasd.org

Buesa, M.; Martínez-Pellitero, M.; Heijs, J.; and Baumert, T. (2002). Los sistemas regionales de innovación en España: tipología basada en indicadores económicos e institucionales de las Comunidades Autónomas. Economía Industrial n. 347, 15-32.

Buesa, M.; Martínez-Pellitero, M.; Baumert, T.; and Heijs, J. (2007). Novel applications of existing econometric instruments to analyse regional innovation systems: the Spanish case (pp. 155-175). In Suriñach et al. (eds.) Knowledge Externalities, Innovation Clusters and Regional Development. Cheltenham: Edward Elgar.

Cheshire P. and Hay, D. (1989). Urban Problems in Europe, London: Allen and Unwin.

Christopherson, S. and Clark, J. (2007). Power in Firm Networks: What it Means for Regional Innovation Systems. Regional Studies Vol 41.9: 1223-1236.

Clarysse, B. and Muldur, U. (1999). Regional cohesion in Europe? An analysis of how EU public RTD support influences the techno-economic regional landscape. European Commission, Directorate General for Science, Research and Development, Working Papers n. 1, January.

Cooke, P. (1992). Regional Innovation Systems: Competitive Regulation in the New Europe. Geoforum n. 23: 365-382.

Cooke, P. (1998). Introduction: origins of the concept (pp. 2-25). In Braczyk, H.J. et al. Regional Innovation Systems. The role of governances in a globalized world. London: UCL Press. 
Cooke, P. (2005). Regionally asymmetric knowledge capabilities and open innovation. Exploring 'Globalisation 2' -A new model of industry organization. Research Policy n. 34: 1128-1149

Cooke, P. and Morgan, K. (1998). The associational economy. Firms, Regions, and Innovation. Oxford: Oxford University Press.

Cooke, P.; Davies, C. and Wilson, R. (2002). Innovation Advantages of Cities: From knowledge to Equity in Five Basic Steps. European Planning Studies vol.10, n. 2: 233-250.

Cooke, P.; Heidenreich, M. and Braczyk, H. (2004). Regional Innovation Systems. London: Routledge.

Cooke, P.; Laurentis, C.; Tödtling, F. and Trippl, M. (2007). Regional Knowledge Economies. Markets, Clusters and Innovation. Cheltenham: Edward Elgar.

Crescenzi, R.; Rodríguez-Pose, A. and Storper, M. (2007). The territorial dynamics of innovation: a Europe-United States comparative analysis. Journal of Economic Geography n. 7: 673-709.

Doloreux, D. (2004). Regional Innovation Systems in Canada: A Comparative Study. Regional Studies vol.38.5: 481-494

Doloreux, D. and Parto, S. (2004). Regional Innovation Systems: A critical synthesis. United Nations University, Institute for New Technologies, Discussion Paper Series n. 17, August.

Dosi, G.; Llerena, P. and Labini, M.S. (2005). Evaluating and Comparing the innovation performance of the United States and the European Union. Expert report prepared for the Trend Chart Policy Workshop 2005.

Ecotec (2005). The Territorial Impact of EU Research and Development Policies. ESPON 2.1.2.

Edquist, C. (2005). Systems of Innovation. Perspectives and Challenges (pp. 181-208). In Fagerberg, J. et al. (eds.) The Oxford Handbook of Innovation. Oxford: Oxford University Press.

Evangelista, R.; lammarino, S.; Mastrostefano, V. and Silvani, A. (2002). Looking for Regional Systems of Innovation: Evidence from the Italian Innovation Survey. Regional Studies vol. 36, 2: 173-186.

Fernández-Satto, V. and Vigil-Greco, J.I. (2007). Clusters y desarrollo territorial. Revisión teórica y desafíos metodológicos para América Latina. Economía, Sociedad y Territorio vol. VI, n. 24: 859-912.

Freeman, C. (ed.) (1987). Technology policy and economic performance: Lessons from Japan. London: Pinter.

Fritz, M. (2002). Measuring the Quality of Regional Innovation Systems: A Knowledge Production Function Approach. International Regional Science Review n. 25: 86-101.

Hollanders, H. (2007). 2006 European Regional Innovation Scoreboard (2006 RIS). European Trend Chart on Innovation.

Hommen, L. and Doloreux, D. (2003). Is the regional Innovation System Concept at the End of Its Life Cycle? Paper presented to Innovation in Europe: Dynamics, Institutions and Values, Roskild University, Dinamarca.

Howells, J. (2005). Innovation and regional economic development: A matter of perspective? Research Policy n. 34: 1220-1234.

Lundvall, B-A. (ed.) (1992). National Systems of Innovation. Towards a Theory of Innovation and Interactive Learning. London-New York: Pinter.

Lundvall, B-A. (2007). National Innovation Systems-Analytical Concept and Development Tool. Industry and Innovation Vol.14, n. 1: 95-119.

MacKinnon, D.; Cumbers, A. and Chapman, K. (2002). Learning, innovation and regional development: a critical appraisal of recent debates. Progress in Human Geography n. 26: 293-311.

Malik, K. and Cunningham, P.N. (2006). Trans-national Policy Learning in Europe: attempts to transfer innovation policy practices, Innovation: Management, Policy \& Practice Journal vol. 8(6): 262-272

Malmberg, A. and Maskell, P. (1997). Towards an explanation of regional specialization and industrial agglomeration. European Planning Studies n. 5 (1): 25-41.

Malmberg, A. and Maskell, P. (2001). The elusive concept of localization economies. Paper for the 'Industrial Clusters' Revisited: Innovative Places or Uncharted Spaces? Session, AAG Annual Conference, New York.

Markusen, A. (1999). Fuzzy Concepts, Scanty Evidence, Policy Distance: The Case for Rigour and Policy Relevance in Critical Regional Studies. Regional Studies vol.33 (9): 869-884.

Martínez-Pellitero, M. (2002). Recursos y resultados de los sistemas de innovación: elaboración de una tipología de sistemas regionales de innovación en España. IAIF working paper $\mathrm{n}$. 34. Downloadble from: http://www.ucm.es/bucm/cee/iaif 
Martínez Pellitero, M. (2007). Los sistemas regionales de innovación en Europa: tipología y eficiencia (pp. 215-256). M. Buesa y J. Heijs (coord.) Sistemas regionales de innovación: nuevas formas de análisis y medición. Madrid: Fundación de las Cajas de Ahorros.

Martínez-Pellitero, M. and Baumert, T. (2003). Medida de la capacidad innovadora de las Comunidades Autónomas españolas: construcción de un índice regional de la innovación. IAIF working paper n. 35, Universidad Complutense de Madrid. Downloadble from: http://www.ucm.es/bucm/cee/iaif

Maskell, P. and Malmberg, A. (1999). Localised learning and industrial competitiveness. Cambridge Journal of Economics n. 23: 167-185.

Miles, I. (2005). Innovation in Services (pp.433-458). In Fagerberg, J. et al. (eds.) The Oxford Handbook of Innovation. Oxford: Oxford University Press.

Morgan, K. (2004). The exaggerated death of geography: learning, proximity and territorial innovation systems. Journal of Economic Geography n. 4: 3-21.

Moulaert, F. and Sekia, F. (2003). Territorial Innovation Models: A Critical Survey. Regional Studies n. 37: 289-302.

Mowery, D.C. and Sampat, B.N. (2005). Universities in National Innovation Systems(pp. 209239). In Fagerberg, J. et al. (eds.) The Oxford Handbook of Innovation. Oxford: Oxford University Press.

Muller, E. and Nauwelaers, C. (2005). Enlarging the ERA: identifying priorities for regional policy focusing on research and technological development in the New Members States and Candidate Countries. Final report COP6-CT.2004.00001.

Muscio, A. (2004). From Regional Innovation Systems to Local Innovation Systems: Evidence from Italian Industrial Districts. European Planning Studies Vol. 14, n. 16: 773-789.

Navarro, M. (2007). Los sistemas regionales de innovación. Una literatura con claroscuros. IAIF working paper n. 57.

Navarro, M. and Buesa, M. (dir.) (2003). Sistemas de innovación y competitividad en el País Vasco. San Sebastián: Eusko Ikaskuntza.

Nelson, R.R. (1992). National Innovation Systems: A retrospective on a Study. Industrial and Corporate Change vol. 1, n. 2: 347-374

Nelson, R. R. and Rosenberg, N. (1993). Technical innovation and national systems(pp. 3-21).. In Nelson, R. R. (ed.). National Systems of Innovation: A Comparative Study Oxford: Oxford University Press.

Niosi, J. (2002). National systems of innovations are "x-efficient" (and x-efective). Why some are slow learners. Research Policy n. 31: 291-302.

OECD (2001) Devolution and Globalisation. Implications for local decision-makers. Paris: OECD.

OECD (2007). Globalisation and Regional Economies. Paris: OCDE.

Oughton, C.; Landabaso, M. and Morgan, K. (2002). The regional innovation paradox: Innovation policy and industrial policy, Journal of Technology Transfer n. 27: 97-110.

Porter, M. E. (1990). The Competitive Advantage of Nations. London and Basingstoke: The Macmillan Press.

Porter, M. E. (1998). On competition. Boston: Harvard Business School.

Porter, M.E. (2003). The Economic Performance of Regions. Regional Studies, Vol. 37.6\&7: 549-578.

Rodríguez-Pose, A. (1999). Innovation prone and innovation averse societies. Economic performance in Europe. Growth and Change n. 30: 75-105

Salom, J. (2003). Innovación y actores locales en los nuevos espacios económicos: un estado de la cuestión. Boletín de la A.G.E. n. 36: 7-30.

Schurmann, C. and Talaat, A. (2000). Towards a European Peripherality Index. Final Report. Mimeo. Downloadble from: http://www.raumplanung.unidortmund.de/irpud/fileadmin/irpud/content/documents/publica tions/ber53.pdf)

Scott, A.J. and Storper, M. (2003). Regions, Globalization, Development. Regional Studies Vol. 37.6\&7:579-593.

Sharpe, S. and Martínez-Fernández, C. (2006). Measuring regional knowledge resources: What do knowledge occupations have to offer?. DRUID Summer Conference 2006.

Spiekermann y Neubauer (2002). European Accessibility and Peripherality: Concepts, Models and Indicators. Nordregio Working Paper 2002/9. Downloadble from: http://www.nordregio.se/Files/wp0209.pdf

Sterlacchini, A. (2006). Innovation knowledge and regional economic performances: regularities and differences in the EU. DRUID Summer Conference 2006.

Tödtling, F. and Kaufmann, A. (1999). Innovation Systems in Regions of Europe-A Comparative Perspective. European Planning Studies vol. 7, n. 6: 699-717. 
Tödtling, F. and Trippl, M. (2005). One size fits all? Towards a differentiated regional innovation policy approach. Research Policy n. 34: 1203-1219. 


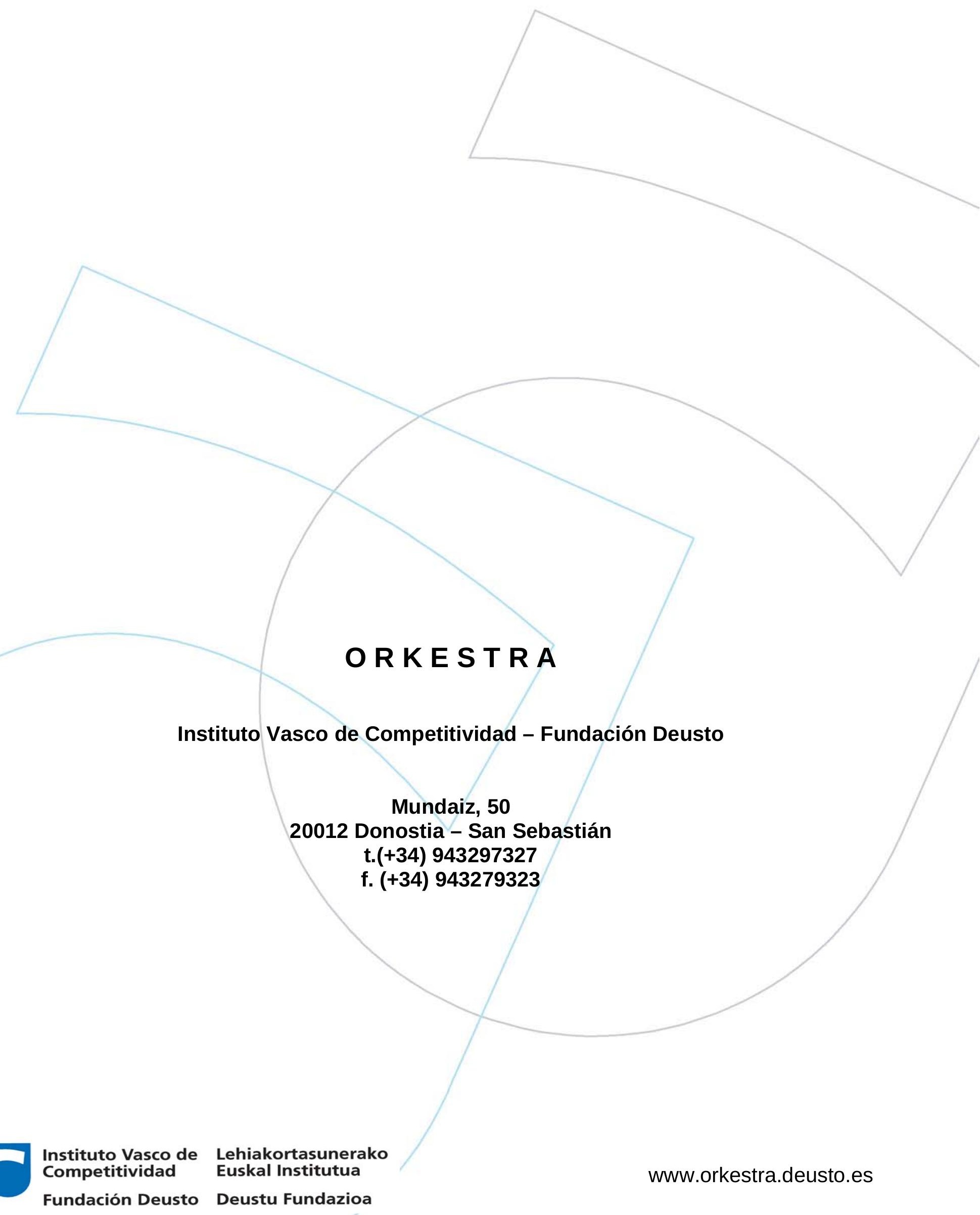

